Poultry Association of Great Britain. Mr. Taylor was appointed to the staff of the Ministry of Agriculture and Fisheries in December 1946 as a poultry advisory officer in the National Agricultural Advisory Service.

\section{Mr. C. S. Windebank}

Mr. C. S. WADEBANK has been appointed managing directo of the Esso Development Company. This Comprny conducts and co-ordinates research, contract Ind patent work for the benefit of the Esso group of petroleum companies in Europe. Mr. Windebank took first-class honours in chemical epgineering at the University of London, and in 1936-37 was at the Massachusetts Institute of Technology, where he was awarded the degree of M.Sc. In 1937 he joined the technical staff of International Association (Petroleum Industry), Ltd., in London, and later, in 1940, he was released from the Army in order to undertake technical work with Esso European Laboratories on aviation fuels. On the formation of the Esso Development Company in $1947 \mathrm{Mr}$. Windebank was made manager of the Research Department.

\section{Royal Society of Eelinburgh : New Fellows}

THE following/were elected fellows of the Royal Society of Edjiburgh at the ordinary meeting held on March 7. Dr. Charlotte Auerbach, 9 Fountainhall Road, Edinburgh 9 ; Dr. R. S. Barclay, statistician to the West Highland Survey; Dr. W. Black, principal scientific officer to the Scottish Society for Research in Plant Breeding; John Cameron, cheriff of Inverness, Moray, Nairn, Ross and Cromarty ; Prof. W. H. J. Childs, Physies Department, Heriot-Watt College, Edinburgh; Dr. Ethel D. Currie, University of Glasgow ; Dr. D. P. Cuthbertson, director of the Rowett Research Institute, Bucksburn, Aberdeen; Dr. A. M. Gillespie, 135 Craiglea Drive, Edinburgh 10; Mr. D. Grant, 19 Falcon Road West, Edinburgh 10; Dr. F. Gross, Zoology Department, University of Edinburgh; Mr. J. Jack, Mayfield, Monktonhall, Musselburgh, Midlothian; Prof. R. V. Jones, Natural Philosophy Department, University of Aberdeen; Dr. Sheina M. Marshall, principal scientific officer, Scottish Marine Biological Association Laboratory, Millport; Mr. N. G. Matthew, 126 West Savile Terrace, Edinburgh 9 ; Dr. Christina C. Miller, Chemistry Department, University of Edinburgh; Mr. H. C. Pawson, assistant director and senior tutor in agriculture, King's College (University of Durham), Newcastleupon-Tyne; Dr. I. A. Preece, 7 Blinkbonny Road, Edinburgh 4 ; Dr. Doris L. Reynolds, 7 West Mains Road, Edinburgh 9 ; Dr. H. O. W. Richardson, Natural Philosophy Department, University of Edinburgh ; Dr. H. Sington, London; Dr. J. Smart, Zoology Department, University of Cambridge ; Dr. R. H. A. Swain, Bacteriological Department, University of Edinburgh; Mr. G. Waterston Harestanes, Longniddry, East Lothian; Mr. R. G. White, director of the Animal Breeding and Research Organisation, Agricultural Research Council; Dr. F. N. Woodward, director of the Scottish Seaweed Research Association.

\section{Use of the Term 'Coliform'}

THE term/coliform' has for some time had an obscure molning, and it has become increasingly clear that a gefinition is desirable. Those interested in medich and veterinary bacteriology have used it to emblace only the morphological characters of many species, not of Bacterium coli alone, but also of the dysentery bacteria, the salmonella and other Gram. negative rods similar to Bacterium coli. On the other hand, the term 'coliform' is restricted by many water and dairy bacteriologists to those organisms which are not only morphologically similar to Bacterium coli but which also resemble it in its cultural and biochemical characteristics ; some have even regarded it as being synonymous with Bacterium coli of fæcal origin. Because of this confusion and also because there is now a closer liaison between all those who study bacteria from whatever aspect, a committee of nine representing this variety of interests was appointed by the Society for General Microbiology and by the Society for Applied Bacteriology. This committee met on several occasions to discuss various aspects of the matter, and it is hoped that bacteriologists in general will be able to agree upon the meaning of the term 'coliform' which has been put forward.

Dr. Reginald Lovell (for the Society for General Microbiology), Royal Veterinary College, London, N.W.1, and Dr. C. B. Taylor (for the Society for Applied Bacteriology), c/o Messrs. Lever Brothers and Unilever, Ltd., Port Sunlight, Cheshire, have forwarded the following relevant portions of the committee's report: “(I) The term 'coliform' means 'like Bacterium coli', or 'coli-like'. (2) 'Coliform' is an adjective, and as such has no generic or ecological significance. (3) It is proposed that the term 'coliform' should refer to Gram-negative rods resembling Bacterium coli in morphology and staining reactions, but not necessarily in cultural and biochemical characteristics. (4) That the widest publicity should be given to this definition to prevent the term being employed to define different specific types by different workers, or to restrict the term to particular branches of bacteriology. The committee is convinced that the proposed definition is the only one satisfactory to all interests in bacteriology and is opposed to any definition based on ecology or biochemical reactions. Existing systems allow for classification of organisms grouped under the wide term now proposed."

\section{University of Birmingham}

AT the annual meethy the Court of Governors of the University of 1 . Angham, the Pro-Chancellor, Mr. Sydney denced, announced that the progress of building at be-University would be accelerated in the profent fear by an increase in the available supplies of material and labour. Among the first repiremefts to be met is the extension of the stedents' union. At present a part of the new engin. eering building is well advanced, and it is hoped that a further portion will be undertaken very shortly. The estimated cost of the much-needed halls of residence is such as to postpone indefinitely their realization. Present needs have been met to some extent by the erection of a number of prefabricated huts which are regarded as temporary, though they appear to be more durable than the old wooden Army huts erected in 1919, some of which are still in use. The doubling of the University population during the ten years following the War was regarded as being in the national interest; but Birmingham has already more than achieved this aim, the present number of students being between 3,250 and 3,500 , a figure at which the Vice-Chancellor considers it might well be stabilized.

Among experiments aimed at broadening the education of the undergraduate, mention was made of 